\title{
Thermal Characteristics Evaluation of Vegetables Oil to be Used as Phase Change Material in Air Conditioning System
}

\author{
Yuli S. Indartono ${ }^{1}$, Aryadi Suwono ${ }^{1}$, Ari D. Pasek ${ }^{1}$, Didin Mujahidin ${ }^{2}$, Irfansyah Rizal ${ }^{1}$ \\ ${ }^{1}$ Faculty of Mechanical and Aerospace Engineering Institut Teknologi Bandung, Bandung \\ ${ }^{2}$ Faculty of Mathematics and Natural Science Institut Teknologi Bandung, Bandung \\ E-mail: indartono@termo.pauir.itb.ac.id
}

\begin{abstract}
In a typical commercial building, air conditioning system consumes around $60 \%$ of building's electricity. By looking at that number, it is clear that effort to suppress building energy consumption should be directed to air conditioning system. Recently, phase change substances, such as ice slurry, receive broad attention since the substances has ability to save energy in hydronic cooling system. Previous experiments by author showed that certain phase change material, i.e. trimethylolethane trihydrate, is able to save energy of a chiller. However, in Indonesia, the material is quite expensive. In this research, applicability of some lower-price materials, i.e. mixture of vegetables oil and biodiesel, as phase change material in secondary refrigerant were evaluated. Some thermal characteristics, such as freezing and melting temperatures, and also latent heat of the oils are explained in this paper.
\end{abstract}

Keywords: Phase change material, vegetable oil, secondary refrigerant, air conditioning system.

\section{INTRODUCTION}

With increasing severe impact of global warming, human focuses on mitigation and adaptation effort to avoid the worst impact caused by high Green House Gases (GHGs) concentration in the atmosphere. There are four alternatives that can be done in energy sector, i.e. diversification, conservation and efficiency, fuel switching to the lower carbon-emission fuel, and carbon capture \& storage. Electricity savings in buildings can be obtained by improving efficiency of air conditioning systems, since the systems take a large amount of building electricity; in Indonesia, the figure is around 60\%. High electricity consumption of air conditioning system also occurred in USA, Japan, and China $[1,2,3]$.

Air conditioning technology also deals with the ozone layer depletion problem. Experts believe that the ozone layer depletion is caused by chemicals, such as R-12, R-11, and R-22 [4]; three popular refrigerants in their time. R-12 and R-11 have been phased-out in many countries, while R-22 is still abundant. The refrigerants break the ozone molecules when they are leaked or released from refrigeration and air conditioning systems. One technology to limit refrigerant amount in a big capacity of air conditioning machine is by using indirect refrigeration system. Secondary refrigerant, such as chilled water, is circulated through building to absorb thermal load from Air Handling Unit (AHU) or directly from rooms by using Fan Coil Unit (FCU).
To increase heat transfer coefficient and thermal capacity of the secondary refrigerant, some researchers used phase change material (PCM) in latent heat transportation system [5]. They usually use ice slurry as PCM. Inaba [5] pointed out that the latent heat transportation system has significant improvement in down-sizing of piping network equipment, reduce heat loss, increase heat capacity and enhance heat transfer coefficient in heat exchanger. However, ice slurry needs lower temperature of the chiller. This sacrifices chiller performance. To avoid that condition, other higher solidificationtemperature phase change material should be used.

Previous work by author [6] showed that application of trimethylolethane trihydrate (TME) as phase change material in secondary refrigerant can reduce chiller energy consumption significantly. TME slurry can be produced at normal temperature range of typical air conditioning system. That is why TME application does not reduce chiller performance. However, for large scale application, mainly in Indonesia, TME is quite expensive. This research evaluates some thermal properties of vegetables oil mixture which are cultivated in Indonesia, so their prices are lower compared to that of TME.

In general, there are three ways for material storing energy, those are sensible heat, latent heat, and in form of chemical energy [7]. Latent heat storage is one of the most efficient way of storing thermal energy. Unlike sensible heat storage method, latent heat storage method provides much higher storage density, with a smaller temperature difference between storing and releasing heat [8]. 
Latent heat storage substances typically can be classified as organics and inorganics. Main advantage of inorganics substances over the organics is its higher latent heat, while organics substance has advantage on non corrosiveness, low or non undercooling, also chemical and thermal stability. Organic substances can be classified further as paraffin and fatty acid [7].

To be used as phase-change secondary refrigerant in an air conditioning system, a substance or mixture of substances must show phase change (solid-liquid) phenomenon around working temperature of the air conditioning system. Typical phase change temperature needed in air conditioning system is $9-10^{\circ} \mathrm{C}$. Researchers reported that some pure fatty acids, such as propyl palmiate and isopropyl palmiate have melting temperature of 10 and $11^{\circ} \mathrm{C}$ [7]. Some kind of paraffins also have phase change temperature around the required temperature range of air conditioning systems $[7,9,10]$. However, in Indonesia paraffin has comparable price with TME, while pure fatty acids, such as lauric and capric acids are also expensive.

By considering that aforementioned conditions, the reasonable choice is investigating organic substances which are locally-available and quite cheap, such as palm or coconut oil. It is known that palm oil has higher solidification temperature to compared coconut oil. From DSC (Differential Scanning Calorimetry) measurement, it was shown that the first solidification sign of palm and coconut oil appear at about 47 and $27^{\circ} \mathrm{C}$ [11]. Ōzonur, et.al. [12] reported that natural coconut fatty acid melts within $22-24^{\circ} \mathrm{C}$. They used microencapsulation of coconut fatty acid for thermal energy storage at range of $22-34^{\circ} \mathrm{C}$. On the other hand, trancesterification offers the possibility to change the physical characteristics, especially the crystallization properties of fats and oils; while fatty acids themselves remain unchanged [13]. For example, it can be seen from [14] and [15] that coconut oil has similar percentage of fatty acids concentration compared to coconut-based biodiesel. Transesterification, often called alcoholysis, is the reaction of a fat or oil with an alcohol to form esters and glycerol [16]. Nowadays, transesterification of vegetable oils is used worldwide to produce renewable energy called as biodiesel. In this study, transesterification process of vegetable oil is needed to modify the physical properties, mainly crystallization and melting, of the fatty acid. By mixing vegetable oil and its biodiesel, crystallization and melting temperature of the mixture is lower compare to that of the vegetable oil.

In this study, thermal properties of some vegetable oils mixture and biodiesel were evaluated; such as melting and freezing temperatures, and also latent heat. Some vegetable oils which are used in this experiment are coconut oil, palm oil, jathropha curcas oil, frying oil, and biodiesel from palm oil. By investigating the thermal properties of those oils, appropriate oil to be used as phase change material in secondary refrigerant can be selected.

\section{RESEARCH METHODOLOGY}

First step of this experiment is evaluating the proper compositions for each oil combinations. Criterion to select an appropriate composition is phase change temperature of the mixture, i.e. around typical temperature range of secondary refrigerant (chilled water). This range of temperature can be produced by typical chiller; so it will not sacrifice chiller performance when producing phasechange slurry. Macroscopic indication of the phase change phenomenon is constant temperature over a certain range of time. This macroscopic property was measured by using thermometer and thermocouple connected to data acquisition system. Then, thermal characteristics of the selected mixture, such as freezing and melting points and also latent heat, were evaluated by Differential Scanning Calorimeter (DSC).

\section{Material}

Materials used in this experiment are coconut oil (CCO) and its biodiesel (CCOB), bulk palm oil (PO) and its biodiesel (POB), Jathropa Curcas oil (JCO), and cooking oil (CO). The coconut oil is 'Braco' food-grade oil produced by CV Balangan Raya Abadi Indonesia. Bulk palm oil was bought from a traditional market in Bandung. Jathropa Curcas oil was supplied by Chemical Engineering Laboratory at Institut Teknologi Bandung, Indonesia. Frying oil used in this experiments is food grade 'Sania' produced by PT. Wilmar Internasional. Coconout-oil and palm-oil biodiesel were supplied by Chemical Engineering Laboratory at Institut Teknologi Bandung, Indonesia.

There are 6 oil combinations used in this experiment, i.e. CCO-PO, CCO-CO, CCO-JCO, POBCO, POB-CCOB, POB. Based on the oil properties, the aforementioned combinations have possibility to show phase change at typical temperature range of secondary refrigerant (chilled water).

\section{Equipment}

Equipments used in this experiment are thermometer, thermocouple connected to data acquisition, magnetic stirrer, cooling bath, and Digital Scanning Calorimetry (DSC). The thermometer is "Sense" thermal-expansion type, produced by Germany. Thermocouple and data acquisition (TC-08) is produced by Omega Engineering. The cooling bath is 
"Frigomix" produce by Braun Melsungen AG (Germany). The Magnetic stirrer is "RET" produced by IKAMAG (Germany); this stirrer is equipped with a heater. While DSC used in this experiment is DSC Metler Toledo Type 820.

\section{RESULT AND DISCUSSION}

\section{Evaluation of Phase Change Temperature}

Evaluation of mixture freezing temperature was conducted by cooling the mixture contained in glass which was placed in cooling bath. The cooling bath temperature was reduced and maintained close to $0^{\circ} \mathrm{C}$. Some mixtures show freezing temperature around working temperature of chiller evaporator. The results are shown in Figure 1 until Figure 6.

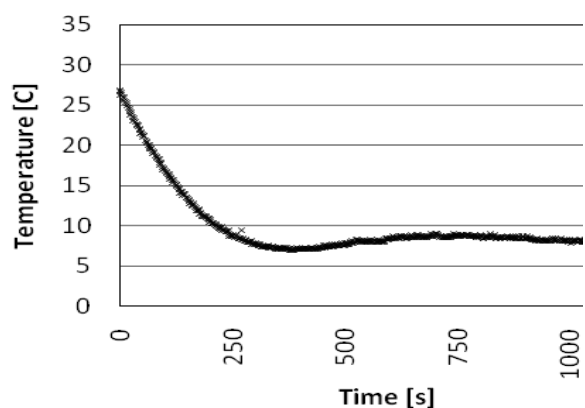

Figure 1. Freezing Temperature of CCO \& PO Mixture with Mass Ratio 20:10g

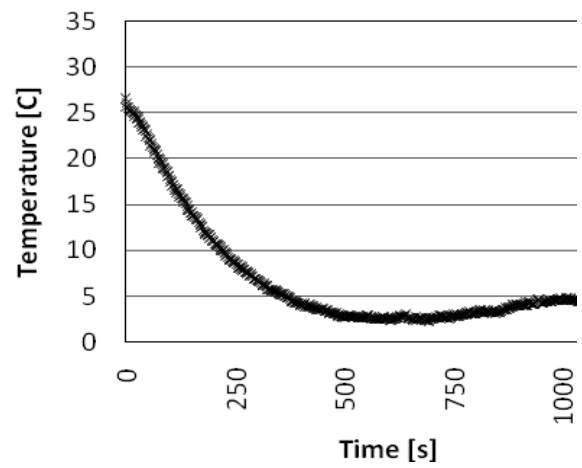

Figure 2. Freezing Temperature of CCO \& CO Mixture with Mass Ratio 15:15g

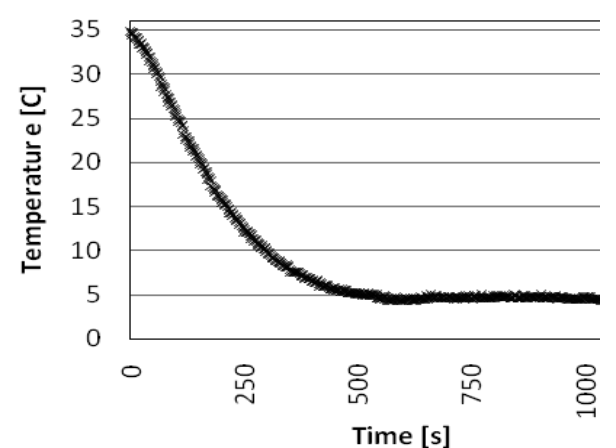

Figure 3. Freezing Temperature of CCO \& JCO Mixture with Mass Ratio 15:15g

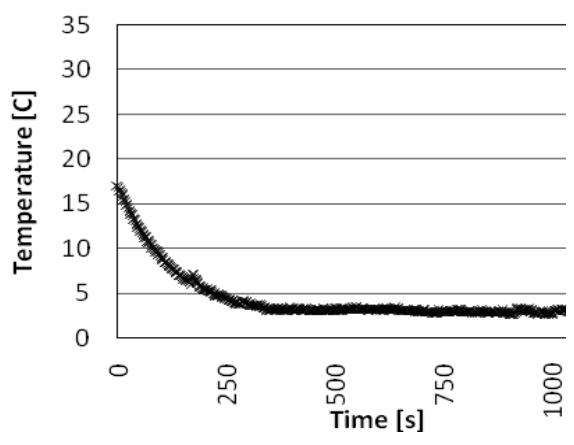

Figure 4. Freezing Temperature of POB \& CO Mixture with Mass Ratio 45:5g

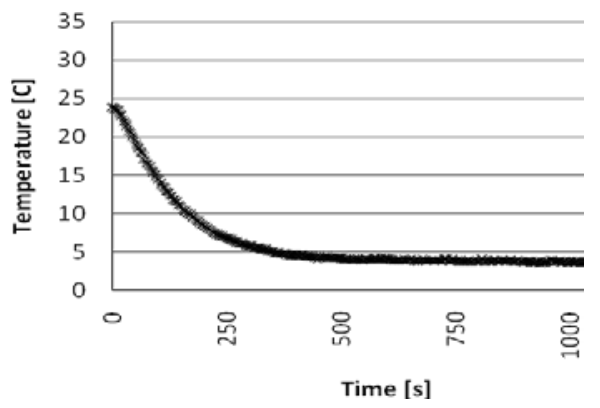

Figure 5. Freezing Temperature of POB \& CCOB Mixture with Mass Ratio 25:5g

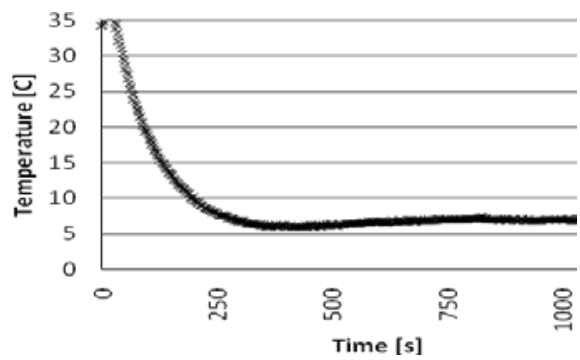

Figure 6. Freezing Temperature of Palm Oil Biodiesel (POB)

Table 1. Oil Mixtures and Their Phase-Change Temperature

\begin{tabular}{cccc}
\hline $\begin{array}{c}\text { Vegetable } \\
\text { Oil }\end{array}$ & $\begin{array}{c}\text { Mass Ratio } \\
\text { Composition } \\
\text { [g:g] }\end{array}$ & $\begin{array}{c}\text { Freezing } \\
\text { Temperature } \\
{\left[{ }^{\circ} \mathbf{C}\right]}\end{array}$ & $\begin{array}{c}\text { Melting Starting } \\
\text { Temperature } \\
\text { [oC] }\end{array}$ \\
\hline CCO : PO & $2: 1$ & $7.1-8.9$ & $10-12$ \\
CCO : CO & $1: 1$ & $2.6-4.5$ & $10-11$ \\
CCO : JCO & $1: 1$ & $4.3-4.8$ & $10-11$ \\
POB : CO & $9: 1$ & $2.6-3.2$ & $10-11$ \\
POB : CCOB & $5: 1$ & 4 & $10-11$ \\
POB & $100 \%$ & $6-7$ & 10 \\
\hline
\end{tabular}

In some figures, mainly in Figures 1 until Figure 3, small temperature variation during freezing can be observed. This phenomenon may be caused by latent heat released by the mixtures. Mohamed [17] also reported small temperaturevariation observed in his water solidification experiment.

After freezing, samples were heated until they start melting. The aforementioned freezing and melting temperatures are shown in Table 1. 
Since typical chilled water exits from chiller at around $6^{\circ} \mathrm{C}$, almost all vegetable oils mentioned in Table 1 are suitable to be used in typical chiller (without changing temperature setting). Temperature shifting between freezing and melting is typical for vegetable oils, since thermal behaviour of vegetable oil during cooling and heating is different [18]. However, all melting temperature mentioned in Table 1 are acceptable for application in Fan Coil Unit (FCU).

\section{Latent Heat Measurement}

Latent heat measurement was done by using Differential Scanning Calorimetry (DSC). Samples measurement was recorded from $-30^{\circ} \mathrm{C}$ to $30^{\circ} \mathrm{C}$, then it was held at 1 minute, and continued with cooling from $30^{\circ} \mathrm{C}$ to $-30^{\circ} \mathrm{C}$. Temperature change for heating and cooling is $2^{\circ} \mathrm{C} /$ minute. Six samples with same composition shown in Table 1 were evaluated in DSC machine. Results of the measurements are shown in Figure 7. In the Figure 7, Sample 1 is CO \& POB, Sample 2 is PO \& CCO, Sample 3 is CCO \& CO, Sample 4 is CCOB \& POB, Sample 5 is CCO \& JCO, while Sample 6 is POB.

Some thermal characteristics of the aforementioned mixtures are explained in Table 2 and Table 3.

Table 2. Melting Characteristics of the Oil Mixtures

\begin{tabular}{cccccc}
\hline Vegetable Oil & $\begin{array}{c}\text { Mass } \\
\text { Ratio }\end{array}$ & $\begin{array}{c}\text { Melting } \\
\text { Onset } \\
\text { Temp. } \\
{\left[{ }^{\circ} \mathbf{C}\right]}\end{array}$ & $\begin{array}{c}\text { Melting } \\
\text { Peak } \\
\text { Temp. } \\
{\left[{ }^{\circ} \mathbf{C}\right]}\end{array}$ & $\begin{array}{c}\text { Melting } \\
\text { Compl. } \\
\text { Temp. } \\
{\left[{ }^{\circ} \mathbf{C}\right]}\end{array}$ & $\begin{array}{c}\text { Melting } \\
\text { Heat } \\
{[\mathbf{k J} / k g]}\end{array}$ \\
\hline CCO : PO & $2: 1$ & -8 & 13.12 & 18.91 & 93.13 \\
CCO : CO & $1: 1$ & -12 & 9.39 & 16.74 & 84.47 \\
CCO : JCO & $1: 1$ & -19 & 9.12 & 16.02 & 70.10 \\
POB : CO & $9: 1$ & -15 & 6.5 & 13 & 60.82 \\
POB : CCOB & $5: 1$ & -18 & 9.93 & 12.36 & 59.11 \\
POB & $100 \%$ & -15 & 12.21 & 14.38 & 70.4 \\
\hline
\end{tabular}

Table 3. Crystallization Characteristics of the Oil Mixtures

\begin{tabular}{|c|c|c|c|c|c|}
\hline Vegetable Oil & $\begin{array}{l}\text { Mass } \\
\text { Ratio }\end{array}$ & $\begin{array}{c}\text { Crystal- } \\
\text { lization } \\
\text { Onset } \\
\text { Temp. } \\
{\left[{ }^{\circ} \mathrm{C}\right]} \\
\end{array}$ & $\begin{array}{c}\text { Crystalli } \\
\text { zation } \\
\text { Peak } \\
\text { Temp. } \\
{\left[{ }^{\circ} \mathrm{C}\right]}\end{array}$ & $\begin{array}{c}\text { Crystal- } \\
\text { lization } \\
\text { Compl. } \\
\text { Temp. } \\
\text { [ } \mathrm{C}]\end{array}$ & $\begin{array}{c}\text { Crystal- } \\
\text { lization } \\
\text { Heat } \\
{[\mathrm{kJ} / \mathrm{kg}]}\end{array}$ \\
\hline $\mathrm{CCO}: \mathrm{PO}$ & $2: 1$ & 5 & -7.39 & -21 & 81.27 \\
\hline $\mathrm{CCO}: \mathrm{CO}$ & $1: 1$ & 5.5 & -2.43 & -18 & 61.07 \\
\hline CCO : JCO & $1: 1$ & 1 & -13.12 & -27 & 52.06 \\
\hline POB : CO & $9: 1$ & 2.32 & 1.98 & -21 & 58.90 \\
\hline POB : CCOB & $5: 1$ & 4 & 2.32 & -22 & 60.79 \\
\hline POB & $100 \%$ & 6 & 4.5 & -18 & 68.99 \\
\hline
\end{tabular}

Three Palm-Oil Biodiesel (POB) based mixtures, i.e. $\mathrm{POB} \& \mathrm{CO}, \mathrm{POB} \& \mathrm{CCOB}$, and $\mathrm{POB}$, do not show double peaks in their crystallization curves (see Figure 7). This feature may be caused by dominant POB composition in the mixture. On the contrary, three Coconout-Oil (CCO) based mixtures, i.e. CCO \& PO, CCO \& CO, CCO \& JCO, show double peak feature in their crystallization curve (see Figure 7). This may be caused by equal composition between substances (except CCO:PO = 2:1). This equality (or near equality) shows each substance characteristic in the crystallization curve.

Solidification temperatures explained in Table 1 are slightly difference compared to crystallization in Table 3. The difference of solidification/crystallization temperature measured by thermocouple and DSC may be caused by difference cooling rate applied to the samples. Cooling rate applied in DSC is $2^{\circ} \mathrm{C} / \mathrm{min}$, while in macroscopic measurement by using thermocouple is around $5^{\circ} \mathrm{C} / \mathrm{min}$. Mihara et al. [19] and Tippets and Martini [20] showed in their experiments that lower cooling rate delays crystallization of vegetable oil. The similar phenomenon is also observed in this experiment.

Eventhough crystallization range has intersection with melting range (see Table 2 and Table 3), but

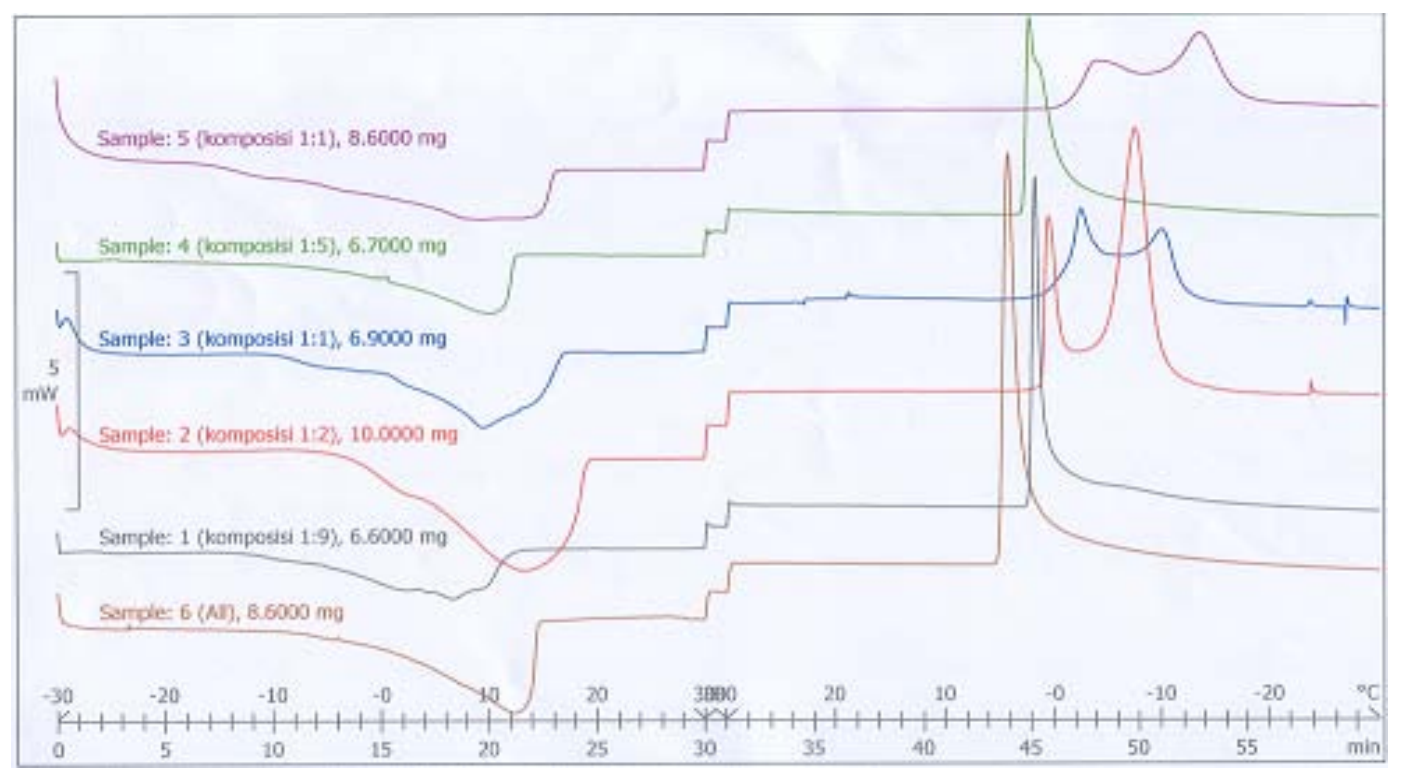

Figure 7. Thermal Characteristics Measurement by Using DSC for the Six Samples 
they are not identical. Tan \& Che Man [16] who measured various vegetable oil characteristics by using DSC also found similar finding. They mentioned that polymorphism of oil and fat is responsible for different crystallization and melting characteristics.

In Table 1, measurement of melting starting/ onset temperature was done macroscopically by using thermometer. This measurement was conducted by heating samples that just solidify. Since the thermometer probe is quite large, it cannot measure micro-melting experienced by oil. On the other hand, before the DSC generated melting curve, the samples were cooled until $-30^{\circ} \mathrm{C}$. Compare to macroscopic measurement by thermometer, DSC probe melting precisely. It is interesting to see that, in general, melting starting temperatures in Table 1 are close with melting peak temperatures in Table 2.

Crystallizatoin heat capacity of POB based mixtures do not different significantly to their melting heat values (see Tables 2 and Table 3). This characteristic is different to that found by Wang and Briggs [18] who explained that their soybean-oils crystallization heat is much smaller than its melting heat value. While crystallization heat of CCO based mixtures are smaller compared with their melting heat values; this characteristic is similar to Wang and Briggs's finding [18]. Similar to Tan and Che Man [14], Wang and Briggs [18] also stated that polymorphism is responsible for different characteristics between melting and crystallization of vegetable oils.

Based on melting heat values, three mixtures show higher latent heat, i.e. CCO \& PO, CCO \& CO, and POB. In indirect air conditioning system, melting heat value is important, since it indicates amount of heat which can be absorbed by the fan coil unit. Based on crystallization onset temperature (Table 3), mixtures of CCO \& PO, CCO \& CO and $\mathrm{POB}$ are also good candidates to be used as phase change materials in an air conditioning system, since they have higher crystallization onset temperature (see Table 3). Higher crystallization temperature does not sacrifice chiller performance when producing slurry.

\section{CONCLUSION}

Study on thermal characteristics of some vegetable oil mixtures was conducted to evaluate their applications as phase change materials used in an indirect air conditioning system. From prelimnary experiment, six samples are promising to be used as the phase change material.

The samples are coconut oil \& bulk palm oil (CCO \& PO), coconut oil \& cooking oil (CCO \& CO), coconut oil \& jathropa curcas oil (CCO \& JCO), biodiesel from palm oil \& cooking oil (POB \& CO), biodiesel from palm oil \& biodiesel from coconut oil (POB \& CCOB), and biodiesel from palm oil (POB).

Further investigation using DSC evaluate freezing and melting temperatures more precisely and measure heat capacity of the mixtures. From this evaluation, three mixtures show higher melting heats i.e. $\mathrm{CCO} \& \mathrm{PO}, \mathrm{CCO} \& \mathrm{CO}$, and POB. Based on crystallization onset temperature, $\mathrm{CCO} \& \mathrm{PO}$, $\mathrm{CCO} \& \mathrm{CO}$, and $\mathrm{POB}$ also show highest value, around $5-6^{\circ} \mathrm{C}$. This high crystallization value does not sacrifice chiller performance.

To evaluate applicability of the aforementioned mixtures, it is important to use selected mixtures as phase change material in secondary refrigerant (chilled water).

\section{Acknowledgement}

This work was financially supported by "Hibah Penelitian Strategis Nasional DIKTI" (Contract No. 035/TL-J/DIPA/SPK/2010) from the Ministry of National Education, the Republic of Indonesia, through Institut Teknologi Bandung (ITB).

\section{REFERENCES}

1. Todesco, G., Chillers + Lightning + TES Why CFC Chiller Replacement Can Be EnergySavings Windfall, ASHRAE Journal USA, pp. 18-27, October 2005.

2. Suzuki, H., Fuller, G.G., Nakayama, T., et.al., Development Characteristics of Drag-Reducing Surfactant Solution Flow in a Duct, Rheol Acta, 43, pp. 232-239, 2004.

3. Saito, A., Recent Advances in Research on Cold Thermal Energy Storage. Int. J. Refrigeration, 25, pp. 177-189, 2002.

4. Fahey, D.W., Twenty Questions and Answers About the Ozone Layer: 2006 Update, United Nations Environment Protection, 2006.

5. Inaba, H., New Challenge in Advanced Thermal Energy Transportation Using Functionally Thermal Fluids, Int. J. Therm. Sci., 39, pp. 991-1003, 2000.

6. Indartono, Y.S., Setioputro, N.T., Tandian, N.P., et.al., Development of Energy-Saving Air Conditioning System by Substituting Primary and Secondary Refrigerants, Proc. $4^{\text {th }}$ International Conference on Cooling and Heating Technologies, Jinhae, Korea, 28-31 October, 2008.

7. Zalba, B., Marín, J.M., Cabeza, L.F., et.al., Review on Thermal Energy Storage with Phase Change: Materials, Heat transfer Analysis and Application, Applied Thermal Engineering, 23, pp. 251-283, 2003. 
8. Farid, M.M., Khudair, A.M., Razack, S.A.K., et.al., A Review on Phase Change Energy Storage: Materials and Application, Energy Conservation and Management, 45, pp. 1597-1615, 2004.

9. He, B., Martin, V. and Setterwall, F., LiquidSolid Phase Equilibrium Study of Tetradecane and Hexadecane Binary Mixtures as Phase Change Materials (PCMs) for Comfort Cooling Storage, Fluid Phase Equilibria, 212, pp. 97-109, 2003.

10. Royon, L., Perrot, P., Guiffant, G., et.al., Physical Properties and Thermorheological Behaviour of $A$ Dispersion Having Cold Latent Heat Storage Material, Energy Convers. Mgmt., 39, pp. 15291535, 1998.

11. Dyszel, S.M. and Baish, S.K., Chracterization of Tropical Oils by DSC, Thermochimica Acta, 212, pp. 39-49, 1992.

12.Özonur, Y., Mazman, M., Paksoy, H.Ö. and Evliya, H., Microencapsulation of Coco Fatty Acid Mixture for Thermal Energy Storage with Phase Change Material, Int. J. Energy Res., 30, pp. 741-749, 2006.

13. Piska, I., Zárubová, M., Loužecký, T., et.al., Properties and Crystallization of Fat Blends, Journal of Food Engineering, 77, pp. 433-438, 2006.

14.Tan, C.P. and Che Man, Y.B., Differential Scanning Calorimetric Analysis of Edible Oils:
Comparison of Thermal Properties and Chemical Composition, J. American Oil Chemists' Society, 77, pp. 143-155, 2000.

15. Yuan, W., Hansen, A.C. and Zhang, Q., Predicting the Temperature Dependent Viscosity of Biodiesel Fuels, Fuel, 88, pp. 1120-1126, 2009.

16. Jitputti, J., Kitiyanan, B., Rangsungvigit, P., et.al., Transesterification of Crude Palm Kernel and Crude Coconut Oil by Different Solid Catalysts, Chemical Engineering Journal, 116, pp. $61-66,2006$.

17. Mohamed, M.M., Solidification of Phase Change Material on Vertical Cylindrical Surface in Holdup Air Bubbles, Int. J. Refrigeration, 28, pp 403-411, 2005.

18.Wang, T. and Briggs, J.L., Rheological and Thermal Properties of Soybean Oils with Modified FA Compositions, J. American Oil Chemists' Society, 79, 831-836, 2002.

19. Mihara, H., Ishiguro, T., Fukano, H., et.al., Effect of Crystallization Temperature of Palm Oil on Its Crystallization. IV. The Influence of Tripalmitoylglycerol (PPP) on the Crystallization of 1,3Dipalmitoyl-2-Oleoyl-Glycerol (POP) and 1,2Dioleyl-3-Palmitoyl-Glycerol (POO), Journal of Oleo Science, 56, (5), pp 223-230, 2007.

20.Tippetts, M. and Martini, S., Effect of Cooling Rate on Lipid Crystallization in Oil-in-Water Emulsions, Food Research International, Volume 42, Issue 7, pp. 847-855, 2009. 